\title{
Nutrient removal and carbohydrate production potential of indigenous Scenedesmus sp. grown in anaerobically digested brewery wastewater
}

\author{
Zenebe Yirgu ${ }^{1 *}$, Seyoum Leta ${ }^{2}$, Ahmed Hussen² and Mohammed Mazharuddin Khan²
}

\begin{abstract}
Background: The combination of nutrient removal using microalgae from wastewater with carbohydrate production has been considered as a promising approach for sustainable wastewater treatment and production of valuable products such as biofuels. In Ethiopia, urbanization and industrial development are not in tandem with wastewater treatment system The objective of this study was to evaluate nutrient removal and carbohydrate production potential of the indigenous microalgae Scenedesmus sp. grown in anaerobically digested brewery wastewater. The indigenous Scenedesmus sp. was grown in an anaerobically digested brewery effluent in different seasons of the year. The biomass was converted into carbohydrate using microwave, autoclave, and oven as pretreatment, followed by optimization for acid concentrations and hydrolysis time.
\end{abstract}

Result: The overall removal efficiencies for the indigenous Scenedesmus sp. based wastewater treatment system were over 99\%, 92\%, 63\%, 65\% and 75\% for $\mathrm{NH}_{4}{ }^{+}-\mathrm{N}, \mathrm{TN}_{1} \mathrm{PO}_{4}{ }^{3-}-\mathrm{P}, \mathrm{TP}$ and $\mathrm{COD}$, respectively. The concentrations of final effluent quality of these parameters except for phosphorus nutrient were below the permissible discharge limit for brewery effluent standard set by Ethiopian Environmental Protection Authority. With regard to carbohydrate production, microwave-assisted acid hydrolysis with $\mathrm{HCl}$ produced a higher total sugar than that of autoclave and oven pretreatments. Among acid concentrations, $\mathrm{HCl}$ with $3 \mathrm{~N}$ produced a higher total sugar, which is significantly different $(P<0.05)$ to the other acid concentrations. The highest total sugar $\left(233.89 \mathrm{mg} \mathrm{g}^{-1}\right)$ was obtained from microalgal biomass during the 20 min hydrolysis time with $3 \mathrm{~N} \mathrm{HCl}$ and $5 \%(\mathrm{w} / \mathrm{v})$ biomass at 1000 watts and $120^{\circ} \mathrm{C}$.

Conclusions: This study showed that there is an opportunity for using the indigenous microalgae for sustainable wastewater treatment and for carbohydrate production that uses as bioethanol source in Ethiopia.

Keywords: Anaerobic digestion, Brewery wastewater treatment, Microwave assisted hydrolysis, Scenedesmus sp., Total sugar

\section{Background}

Brewery industry is one of the agro-industries that consume more water and produce a huge amount of wastewater. Brewery wastewater is characterized by high

\footnotetext{
*Correspondence: zeneyw944@gmail.com

1 Department of Environmental Science, Wolaita Sodo University, Wolaita Sodo, Ethiopia

Full list of author information is available at the end of the article
}

content of organic matter such as chemical oxygen demand (COD) and biological oxygen demand (Akunna et al. 2015). Anaerobic digestion has widely been used for the treatment of this wastewater (Baloch et al. 2007; Alvarado-Lassman et al. 2008). The removal efficiencies of anaerobic digestion are generally about $80 \%$ to $90 \%$ COD (Akunna et al. 2015). However, the effluent generated from anaerobic digestion contains a relatively high amount of nutrients like ammonium and phosphorus 
with low content of chemical oxygen demand (Cai et al. 2013; Delrue et al. 2016). This indicates that further nutrient removal using nitrification and denitrification process is very difficult because of the low concentration of COD and the needs for an external carbon source (Wang et al. 2015).

In Ethiopia, most brewery industries have been using anaerobic digestion for their wastewater treatment. After anaerobic digestion, some of these industries use mechanical aeration for nitrogen removal and chemical precipitation for phosphorus removals while the others directly discharge into the river water. However, both these approaches are unsustainable because the former generally requires high cost, consumes high energy, produces a huge amount of sludge and generates secondary pollutants (Hoffmann 1998; Ruiz-marin et al. 2010; Chaudhary et al. 2017). The latter contributes to the deterioration of receiving water bodies. However, the use of microalgae based treatment for effluent after anaerobic digestion can eliminate the high cost of energy-intensive mechanical aeration to provide oxygen for aerobic treatment process as well as convert nitrogen and phosphorus nutrients into useful biomass (Hu et al. 2019). Therefore, microalgae based wastewater treatment can remove nutrients in a less expensive, more efficient and safe way compare to the conventional approaches (Hoffmann 1998; Ding et al. 2015).

The use of microalgae-based treatment wat not a new idea but has been studied since the 1950s and has received much attention in recent decades (Rawat et al. 2011). Microalgae are photosynthetic microorganisms that use energy from the sun to grow, consuming inorganic nutrients and $\mathrm{CO}_{2}$ (Ruiz-martinez et al. 2012), and are suggested as an alternative to the conventional wastewater treatment (Martinez et al. 2000). The use of microalgae-based wastewater treatment potentially has advantages of low operational cost, simultaneously remove nitrogen and phosphorus, don't require chemicals addition, discharge oxygenated effluent in to receiving water bodies, capture $\mathrm{CO}_{2}$, and produce biomass (Arbib and Garrido-pe 2013; Mennaa et al. 2015). Recent studies have reported that the microalgal species such as Chlorella (Kwon et al. 2020; Yu et al. 2019) and Scenedesmus (Nagi et al. 2020; Tripathi et al. 2019) used to remove nutrients (nitrogen and phosphorus) and organic matter (like COD) from raw wastewater and anaerobically digested effluent.

Different studies have been conducted previously on the utilization of microalgae for nutrient removal from anaerobically digested brewery effluent. The removal of $96 \% \mathrm{TN}$ and $91 \%$ TP from brewery AD effluent using Chlorella protothecoides was reported by Darpito et al. (2014) with the maximum of $1.88 \mathrm{~g} \mathrm{~L}^{-1}$ biomass production. Ferreira et al. (2017) also reported that the cultivation of Scenedesmus obliquus in brewery effluent removed a maximum of $89 \%$ total nitrogen and $40.2 \%$ phosphate with $0.94 \mathrm{~g} \mathrm{~L}^{-1}$ of biomass production and $20-26 \%$ of total sugar yield. Therefore, there is a possibility to use the indigenous microalgae such as Scenedesmus sp. for AD brewery effluent treatment in Ethiopia. Scenedesmus sp. is most widely studied microalga genera for wastewater treatments because of its high efficiency of nutrient removal (Dickinson et al. 2013). The efficiency of Scenedesmus sp. in nutrient removal from different wastewater types (i.e., municipal, agricultural, and industrial wastewater) has been reported in several previous studies. For example, Xin et al. (2010) and Mcginn et al. (2012) cultivated Scenedesmus sp. in domestic and municipal effluents in batch mode, reporting that 98\% TN and 96\% TP, and 90\% TN and TP, respectively. Recently, Tripathi et al. (2019) reported a complete removal of nitrogen and phosphorus from municipal secondary effluent using Scenedesmus sp.

Beside nutrient removal, Scenedesmus sp. produce useful biomass in wastewater, which can be used as a potential source for proteins, carbohydrates, pigments and lipids (Ruiz-martinez et al. 2012; Ding et al. 2015). Scenedesmus sp. is a well-known microalga that has able to accumulate carbohydrates (or starch) in its cells and cell walls (Sivaramakrishnan and Incharoensakdi 2018). The carbohydrate present in Scenedesmus sp. was a valuable source for bioethanol production (Mata et al. 2010; Miranda et al. 2012; Sivaramakrishnan and Incharoensakdi 2018). However, pretreatment is needed to extract carbohydrates from microalgal biomass before processing into bioethanol. The use of pretreatment is to breakdown the cell walls of the microalgal biomass and then releases fermentable sugar for bioethanol production (Phwan et al. 2019). Several pretreatments were employed to release carbohydrate from microalgal biomass. For example, microwave and autoclave (Hernández et al. 2015), oven heating (Harun et al. 2011), and autoclave (Miranda et al. 2012) are used to disrupt and to hydrolyze microalgae biomass into monosaccharides. In addition, chemical lysis using acid and alkaline reagents also employed to hydrolyze microalgae biomass (Harun et al. 2011; Miranda et al. 2012). The efficiencies of each pretreatment depend on the characteristics of microalgae, such as cell wall composition and biomolecule production potential (Costa et al. 2020). Therefore, suitable pretreatment methods should be chosen to maximize the carbohydrate extraction from microalgal biomass, which subsequently uses as substrate for bioethanol production.

The coupling of wastewater treatment with biomass production offers a solution for wastewater management issues as well as for the demand of sustainable 
biofuel feedstocks (Sturm and Lamer 2011). Most studies were focused on the combination of AD brewery effluent treatment using Chlorella sp. with lipid extraction (Farooq et al. 2013; Darpito et al. 2014). However, very few studies were conducted to evaluate the combination of microalgal based treatment of AD brewery effluent with carbohydrate production from microalgal biomass. Furthermore, there is lack of concrete and reliable data on the utilization of indigenous microalgae for wastewater treatment with biomass production in Ethiopia. Therefore, this study was conducted to evaluate the performance of indigenous Scenedesmus sp. for treatment of AD brewery effluent in different seasons of the year. Moreover, the biomass obtained after AD brewery effluent treatment was converted into carbohydrate using different pretreatment methods such as microwave, autoclave, and oven heating to evaluate the maximum possibility of carbohydrate/sugar/ production. Additionally, this study was conducted to evaluate the effects of acid concentrations and hydrolysis times on carbohydrate production from microalgal biomass.

\section{Methods and materials Microalgae}

The indigenous microalga used in this study was Scenedesmus sp. which was isolated from water sample of Lake Ziway in Ethiopia. The isolation and characterization was done using a Basel Bold Medium (BBM) (Nichols and Bold 1965), which contained (per liter) $175 \mathrm{mg} \mathrm{KH_{2 }} \mathrm{PO}_{4}$, $25 \mathrm{mg} \mathrm{CaCl} \cdot 2 \mathrm{H}_{2} \mathrm{O}, 75 \mathrm{mg} \mathrm{MgSO} \cdot \cdot 7 \mathrm{H}_{2} \mathrm{O}, 250 \mathrm{mg} \mathrm{NaNO}$, $75 \mathrm{mg} \mathrm{K}_{2} \mathrm{HPO}_{4}, 25 \mathrm{mg} \mathrm{NaCl}$, and $11.42 \mathrm{mg} \mathrm{H}_{3} \mathrm{BO}_{3}, 1 \mathrm{~mL}$ of microelement Stock solution (which consist of: $8.82 \mathrm{~g}$ $\mathrm{ZnSO}_{4} \cdot 7 \mathrm{H}_{2} \mathrm{O}, 1.44 \mathrm{~g} \mathrm{MnCl}_{2} \cdot 4 \mathrm{H}_{2} \mathrm{O}, 0.71 \mathrm{~g} \mathrm{MoO}_{3}, 1.57 \mathrm{~g}$, $\mathrm{CuSO}_{4} \cdot 5 \mathrm{H}_{2} \mathrm{O}$ and $0.49 \mathrm{~g} \mathrm{Co}\left(\mathrm{NO}_{3}\right)_{2} \cdot 6 \mathrm{H}_{2} \mathrm{O}$, per liter $), 1 \mathrm{~mL}$ of Solution-1 (which consist of: $50 \mathrm{~g} \mathrm{Na}_{2}$ EDTA and $3.1 \mathrm{~g}$ $\mathrm{KOH}$, per liter), and $1 \mathrm{~mL}$ of Solution-2 (which consist of: $4.98 \mathrm{~g} \mathrm{FeSO}_{4}$ and $1 \mathrm{~mL}$ concentrated $\mathrm{H}_{2} \mathrm{SO}_{4}$, per liter), and final $\mathrm{pH}$ of 6.8. The isolation process was done by combining capillary pipetting and agar plating methods with a serial dilution following procedures as described in Andersen and Kawachi (2005). It was performed by repeated capillary pipetting, sub-culturing, agar plating and serial dilution. The isolated indigenous microalgae were identified as Scenedesmus sp. by observing the morphological characteristics through a light microscope, and according to the key of identification described in Bellinger and Sigee (2010), Shubert and Gärtner (2015). The inoculum of the isolated Scenedesmus sp. was also prepared using BBM in $1 \mathrm{~L}$ conical flasks under conditions of $5.5 \mathrm{~K}$ lux light intensity and 12:12 light/dark cycle at room temperature.

\section{Brewery wastewater effluent}

The Anaerobically digested (AD) effluent used in this study was taken from St. George Brewery industry found in Addis Ababa City. The AD brewery effluent was collected after UASB reactor using clean and VU-light sterilized plastic containers. The samples of the wastewater were taken in months of December, March, June and October 2018/2019, presenting Winter, Spring, Summer and Autumn seasons of the year, respectively. The samples were immediately transported to the laboratory and filtered using Whatman No. one filter paper. The $\mathrm{AD}$ brewery effluent was characterized for organic content (COD) and nutrient contents $\left(\mathrm{TN}, \mathrm{NH}_{4}{ }^{+}-\mathrm{N}, \mathrm{TP}\right.$ and $\left.\mathrm{PO}_{4}{ }^{3-}-\mathrm{P}\right)$.

\section{Experimental conditions}

The experiments of this study were performed in batch mode by using a $2 \mathrm{~L}$ conical flask as photobioreactors (Oliveira et al. 2017) in each season of the year. The isolated microalgae, Scenedesmus sp. was cultured in triplicate in an unsterilized AD brewery effluent by adding $10 \%$ of inoculums (Ansari et al. 2017a) an exponential phase in flasks with total working volume of $1.6 \mathrm{~L}$. The flasks were illuminated from the top by using six fluorescent lamps (18 W each, PHILIPS) with a maximum surface light illumination of 5.5 Klux (Li et al. 2014) and photoperiod of 12:12 light/dark cycle at room temperature $\left(18-24{ }^{\circ} \mathrm{C}\right)$. The photoperiod was kept using a Time switcher. The flasks were aerated using an aerator to provide $\mathrm{CO}_{2}$ and for mixing the culture. The treatment was done for the period of 18 days in all seasons. At the end of the experiment, the biomass were harvested using a centrifuge and washed with distilled water, and dried using an oven at $60^{\circ} \mathrm{C}$. The dried microalgal biomass pulverized and stored at $4{ }^{\circ} \mathrm{C}$ until carbohydrate /total sugar/ content analysis.

\section{Hydrolysis of microalgae biomass}

The hydrolysis of microalgae biomass were carried out using acid and alkali hydrolytic agents in a microwave (Milestone SK-10 and SK-12, Italy), autoclave (Model, DIXONS and ST3028) and oven (Model, GX65B) as pretreatments. $0.5 \mathrm{~g}$ dried and pulverized microalgae biomass was used for carbohydrate extraction. The carbohydrate was extracted by the acids $\mathrm{HCl}$ and $\mathrm{H}_{2} \mathrm{SO}_{4}$, and alkalis $\mathrm{NaOH}$ and $\mathrm{KOH}$ with the concentration of $3 \mathrm{~N}$, which was chosen according to Miranda et al. (2012). The extraction of carbohydrate using $\mathrm{H}_{2} \mathrm{O}$ used as control. In microwave, $0.5 \mathrm{~g}$ of microalgal biomass was mixed with $10 \mathrm{~mL}$ of $\mathrm{H}_{2} \mathrm{O}, \mathrm{HCl}$, $\mathrm{H}_{2} \mathrm{SO}_{4}, \mathrm{NaOH}$ and $\mathrm{KOH}$ in Teflon vessel sealed with a Teflon cap and subjected to microwave pretreatment at $120^{\circ} \mathrm{C}$ and $1000 \mathrm{~W}$ for $15 \mathrm{~min}$ as modified from Boonmanumsin 
et al. (2012). In autoclave and oven pretreatment, $0.5 \mathrm{~g}$ of microalgal biomass was mixed with $10 \mathrm{~mL}$ of $\mathrm{H}_{2} \mathrm{O}, \mathrm{HCl}$, $\mathrm{H}_{2} \mathrm{SO}_{4}, \mathrm{NaOH}$ and $\mathrm{KOH}$ in a closed test tube and heated at $120^{\circ} \mathrm{C}$ for $30 \mathrm{~min}$ as modified from Miranda et al. (2012) and Harun et al. (2011), respectively.

\section{Optimization of acid concentration and extraction time}

After selection of best pretreatment (i.e., microwave) and hydrolytic agent (i.e., $\mathrm{HCl}$ ) for carbohydrate extraction, the effects of acid concentrations and extraction times were optimized and evaluated. $0.5 \mathrm{~g}$ of microalgal biomass was mixed with $10 \mathrm{~mL}$ of different $\mathrm{HCl}$ concentrations (i.e., 0.1, $0.5,1,2,3,4,5$ and $6 \mathrm{~N}$ ) in sealed digestion Teflon vessel and subject to microwave pretreatment at 1000 watts and $120{ }^{\circ} \mathrm{C}$ for $15 \mathrm{~min}$. Similarly, $0.5 \mathrm{~g}$ of microalgal biomass was suspended in $10 \mathrm{~mL}$ of $\mathrm{HCl}$ concentration (best result of the above) and also subjected to microwave pretreatment at 1000 watts and $120^{\circ} \mathrm{C}$ for different extraction times (i.e., 5, 10, 15, 20, 25 and $30 \mathrm{~min}$ ). Finally, in each pretreatment, the samples were cooled to room temperature and the supernatant which containing the released carbohydrate /total sugars/ was separated by centrifugation.

\section{Analytical methods}

\section{Biomass production and productivity}

The growth of the indigenous Scenedesmus sp. was monitored by measuring the optical density at $680 \mathrm{~nm}\left(\mathrm{OD}_{680}\right)$ (Lee et al. 2013) using a JENWAY spectrophotometer (model 6705). The biomass concentration as the dry weight was determined according to the standard method for the total suspended solids (APHA 1999). A $5 \mathrm{~mL}$ of microalgae suspension was used for the measurement of dry weight by vacuum filtration using pre-heated and weighted glass microfiber filter (Whatman G/FC,). Then, the filters containing microalgae biomass were dried overnight at $105^{\circ} \mathrm{C}$ in an oven and cooled in a desiccator, and the dry weight was measured. The calibration curve was established between dry cell weight and optical density by preparing and measuring five serial dilutions from algal suspension as stock. Equation (1) was obtained from the calibration curve between dry weight and optical density at $680 \mathrm{~nm}$.

$$
\mathrm{DW}\left(\mathrm{g} \mathrm{L}^{-1}\right)=0.95 * \mathrm{OD}_{680}-0.037 \quad \mathrm{R}^{2}=0.9916
$$

The biomass productivity during the cultivation period, $\mathrm{P}_{\mathrm{B}}\left(\mathrm{mg} \mathrm{L}^{-1} \mathrm{~d}^{-1}\right)$, was calculated by using the Eq. (2) (Zhu et al. 2013).

$$
\mathrm{P}_{\mathrm{B}}=\frac{X_{t}-X_{0}}{t_{t}-t_{0}}
$$

where $\mathrm{X}_{0}\left(\mathrm{mg} \mathrm{L}^{-1}\right)$ is the initial biomass concentration at $\mathrm{t}_{0}($ day, $\mathrm{d})$ and $\mathrm{X}_{\mathrm{t}}\left(\mathrm{mg} \mathrm{L}^{-1}\right)$ is the biomass concentration at $t_{t}$ (day, d).

\section{COD and nutrient analysis}

The concentrations of nutrients and COD were determined by taking a sample every 2 days from the microalgae culture after filtration using a $0.45 \mu \mathrm{m}$ syringe filter. The concentration of COD and TN was measured using the COD Digestion Reagent $(\mathrm{HACH})$ and the Total Nitrogen Reagent Set (HACH) according to HACH procedure (HACH 2002), respectively. The measurement of $\mathrm{COD}$ and TN was performed using a $\mathrm{HACH}$ spectrophotometer ( $\mathrm{HACH}$, Loveland, USA). The concentrations of $\mathrm{NH}_{4}{ }^{+}-\mathrm{N}$ and $\mathrm{PO}_{4}{ }^{3-}-\mathrm{P}$ were estimated using the Phenate method and Ascorbic acid method as provided in APHP (1999), respectively. The concentration of TP was determined after persulfate digestion using an Ascorbic acid method, as stated in APHP (1999). The $\mathrm{NH}_{4}{ }^{+}-\mathrm{N}, \mathrm{PO}_{4}{ }^{3-}$ -P and TP concentrations were measured using a JENWAY spectrophotometer (model 6705). The $\mathrm{pH}$ of the wastewater and the culture was measured using HACK $\mathrm{pH}$ meter $\left(\mathrm{HACK}^{\circledR}, \mathrm{HQ} 440 \mathrm{~d}\right.$, Loveland, USA). The removal efficiencies of COD and Nutrients were calculated by using the Eq. (3) (Renuka et al. 2013):

$$
\mathrm{R}_{\mathrm{f}}=\frac{\mathrm{C}_{0}-\mathrm{C}}{\mathrm{C}_{0}} \times 100
$$

where $C_{0}$ and $C$ is the concentration of AD brewery effluent before and after microalgae treatment, respectively.

\section{Total carbohydrate determination}

The total carbohydrate (total sugar) of microalgae biomass was determined using a phenol-sulfuric acid method (Dubois et al. 1956) using the standard curve with glucose. The supernatant obtained after pretreatment was neutralized by adding sodium carbonate $\left(\mathrm{Na}_{2} \mathrm{CO}_{3}\right)$ until the effervescence ceased (Kassim and Bhattacharya 2016). The supernatant solution was then diluted to $50 \mathrm{~mL}$ with distilled water. Afterward $2 \mathrm{~mL}$ was taken using $25 \mathrm{~mL}$ of test tube and $1 \mathrm{~mL}$ of $5 \%$ phenol solution and $5 \mathrm{~mL}$ of $98 \%$ sulfuric acid was added to it. Then, the test tube was vortexed and kept in the $30{ }^{\circ} \mathrm{C}$ water bath for $30 \mathrm{~min}$. Finally, the absorbance was read at $490 \mathrm{~nm}$ and the total sugar was determined based on the standard curve. The measurement of carbohydrate / total sugar/ was done using the JENWAY spectrophotometer (model: 6705).

\section{Data analysis}

All experiments were carried out in triplicate and the results were presented in Table and Figure as mean values and standard deviation (SD). The figures were made using Excel 2013 and the statistical analyses were performed using R-software. The comparisons of mean values of different treatments were conducted using oneway analysis of variance (ANOVA) followed by post hoc 
Tukey's honesty significant differences. The differences were significant at $\mathrm{P}<0.05$.

\section{Result and discussion Characterization of AD Brewery effluent}

The AD brewery effluent was collected in December, March, June, and October for the representation of the four seasons namely Winter, Spring, Summer, and Autumn, respectively. The AD brewery effluent used in this study was characterized for COD, $\mathrm{NH}_{4}-\mathrm{N}$, $\mathrm{TN}, \mathrm{PO}_{4}{ }^{3-}-\mathrm{P}$ and $\mathrm{TP}$ to know their concentrations. Table 1 shows characteristics of the AD brewery effluent used during the experiments in each season with a permissible discharge limit for brewery effluent standard recommended by the Ethiopian environmental protection authority (EEPA). The maximum concentrations of COD, $\mathrm{NH}_{4}{ }^{+}-\mathrm{N}, \mathrm{TN}, \mathrm{PO}_{4}{ }^{3-}$ and $\mathrm{TP}$ obtained were $439.3 \pm 6.11,45.7 \pm 1.61,57.7 \pm 0.58,41.38 \pm 1.0$, $53.5 \pm 1.95 \mathrm{mg} \mathrm{L}^{-1}$, respectively, which were all recorded in a March whereas the minimum concentrations recorded were $370.3 \pm 6.11 \mathrm{mg} \mathrm{L}^{-1} \mathrm{COD}$ in December, $41.3 \pm 1.52 \mathrm{mg} \mathrm{L}^{-1} \mathrm{NH}_{4}{ }^{+}-\mathrm{N}$ in December, $44.3 \pm 1.00 \mathrm{mg}$ $\mathrm{L}^{-1} \mathrm{TN}$ in June, $35.3 \pm 1.03 \mathrm{mg} \mathrm{L}^{-1} \mathrm{PO}_{4}{ }^{3-}-\mathrm{P}$ in June and $47.2 \pm 1.64 \mathrm{mg} \mathrm{L}^{-1} \mathrm{TP}$ in October. Farooq et al. (2013) and Darpito et al. (2014) reported anaerobically digested brewery effluent had concentrations of $100-275 \mathrm{mg} \mathrm{L}^{-1}$ COD, 50-75 $\mathrm{mg} \mathrm{L}^{-1} \mathrm{TN}$, and 10-55 $\mathrm{mg} \mathrm{L}^{-1} \mathrm{TP}$, which were comparable with the findings in this study for TN and TP but not for COD. Results in this study showed that the concentrations of COD, nitrogen and phosphorus nutrients exceeded the permissible discharge limit of brewery effluent standard recommended by EEPA (2003). It was clear that the brewery effluent obtained after the UASB reactor needs further treatment before discharging into the receiving water bodies. Hence, the use of indigenous microalgae for nutrient removal is an alternative option for the treatment of AD brewery effluent. Microalgae growth and removal of nutrients in wastewater are affected by nitrogen to phosphorus ratio (Cai et al.,
2013). N/P ratios in AD brewery effluent of this study ranged from 1:0.89 in June to 1:1.21 in March, which suggested that the $\mathrm{AD}$ brewery effluent was with nitrogen deficiency. However, McGinn et al., (2011) reported that the concentration of $40 \mathrm{mg} \mathrm{L}^{-1}$ ammonia nitrogen and of $1-10 \mathrm{mg} \mathrm{L}^{-1}$ phosphates were adequate to support most of the freshwater algae strain. Therefore, the nutrient concentrations presented in brewery AD effluent were enough to support the growth of microalgae.

\section{Biomass production}

The utilization of nutrients by microalgae enhanced their growth and reduced the nutrient content in the wastewater. As a result, it supports the purpose of wastewater treatment and biomass production (Yang et al. 2016). The cultivations of indigenous Scenedesmus sp. on brewery effluent in this study conducted in four seasons of the year to evaluate biomass production and nutrient removal. Figure $1 \mathrm{a}, \mathrm{b}$ shows the biomass production and productivity obtained after 18 days of treatment at different seasons of the year. The maximum biomass production was obtained on the 17th day in March and October, and on the 18th day in December and June. The results were $1.10 \pm 0.004,1.21 \pm 0.003,0.991 \pm 0.001$ and $0.978 \pm 0.004 \mathrm{~g} \mathrm{~L}^{-1}$ in December, March, June and October, respectively. The maximum biomass productivities achieved were found to be $65.38 \pm 0.31 \mathrm{mg} \mathrm{L}^{-1}$ $\mathrm{d}^{-1}$ in December on day $10,76.40 \pm 0.35 \mathrm{mg} \mathrm{L}^{-1} \mathrm{~d}^{-1}$ in March on day 10, $58.65 \pm 1.08 \mathrm{mg} \mathrm{L}^{-1} \mathrm{~d}^{-1}$ in June on day 13 and $61.97 \pm 0.13 \mathrm{mg} \mathrm{L}^{-1} \mathrm{~d}^{-1}$ in October on day 12. The maximum biomass production and productivity obtained in March were significantly different $(\mathrm{P}<0.05)$ compared with the other three months in Ethiopia. This attribution may be due to the March month in Ethiopia has relatively warmer temperature compared to the other three months. Therefore, the growth of microalgae influenced by room temperature of each season of this study. This indicates that biomass production from indigenous Scenedesmus sp. varied within seasons of this study due

Table 1 Characteristic of Brewery AD effluent. The value indicates means $\pm S D(n=3)$

\begin{tabular}{lllllll}
\hline Parameter & Unit & \multicolumn{2}{l}{ Month of different Seasons } & $\begin{array}{l}\text { Discharge limit } \\
\text { (EEPA 2003) }\end{array}$ \\
\cline { 3 - 6 } & & December & March & June & October \\
\hline $\mathrm{pH}$ & - & $7.7 \pm 0.04$ & $7.45 \pm 0.03$ & $7.25 \pm 0.01$ & $7.50 \pm 0.04$ & - \\
$\mathrm{COD}$ & $\mathrm{mg} \mathrm{L}^{-1}$ & $370.3 \pm 6.11$ & $439.3 \pm 6.11$ & $389 \pm 3.6$ & $399.7 \pm 5.68$ & 250 \\
$\mathrm{NH}_{4}{ }^{+}-\mathrm{N}$ & $\mathrm{mg} \mathrm{L}^{-1}$ & $41.3 \pm 1.52$ & $45.7 \pm 1.61$ & $35.0 \pm 0.91$ & $44.1 \pm 1.5$ & 20 \\
$\mathrm{TN}^{-1}$ & $\mathrm{mg} \mathrm{L}^{-1}$ & $56.7 \pm 0.58$ & $57.7 \pm 0.58$ & $44.3 \pm 1.00$ & $57.0 \pm 1.00$ & 40 \\
$\mathrm{PO}_{4}{ }^{3-}-\mathrm{P}$ & $\mathrm{mg} \mathrm{L}^{-1}$ & $38.1 \pm 0.39$ & $41.38 \pm 1.41$ & $35.3 \pm 1.03$ & $36.5 \pm 1.5$ & - \\
$\mathrm{TP}$ & $\mathrm{mg} \mathrm{L}^{-1}$ & $49.36 \pm 0.46$ & $53.5 \pm 1.95$ & $49.9 \pm 0.97$ & $47.2 \pm 1.64$ & 5 \\
$\mathrm{~N} / \mathrm{P}$ ratio & & $1: 1.45$ & $1: 1.08$ & $1: 0.89$ & $1: 1.21$ & \\
\hline
\end{tabular}



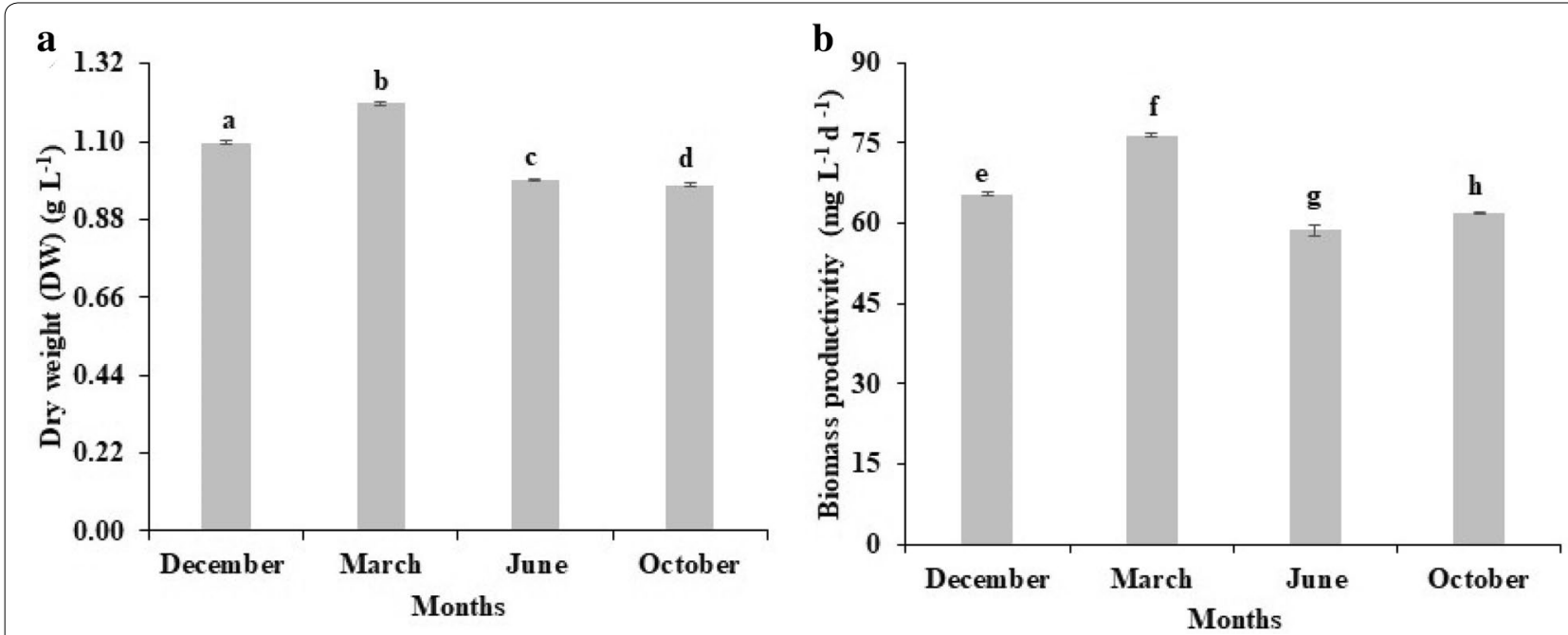

Fig. 1 Biomass production as dry weight (a) and productivity (b) of Scenedesmus sp. grown on AD brewery effluent in different months. The means and standard errors of the three replicates are indicated. ( $P<0.05$ for different letters)

to room temperature variation. The biomass productions obtained in this study were comparable to the finding of Ferreira et al. (2017), who found a maximum of $0.94 \mathrm{~g}$ $\mathrm{L}^{-1}$ using Scenedesmus obliquus in a brewery effluent. But they reported higher biomass productivity $(217 \mathrm{mg}$ $\mathrm{L}^{-1} \mathrm{~d}^{-1}$ ) than that obtained in this study. The biomass production and productivity achieved in this study were lower than those obtained by Farooq et al. (2013), who found $3.22 \mathrm{~g} \mathrm{~L}^{-1}$ and $226.6 \mathrm{mg} \mathrm{L}^{-1} \mathrm{~d}^{-1}$ using Chlorella vulgaris in brewery effluent, respectively. Furthermore, Darpito et al. (2014) reported the biomass production of $1.88 \mathrm{~g} \mathrm{~L}^{-1}$ and productivity of $290 \mathrm{mg} \mathrm{L}^{-1} \mathrm{~d}^{-1}$ using Chlorella protothecoides in a brewery effluent, which was higher than this study. The variation observed in biomass production and productivity among different studies might be due to difference in microalgae type, cultivation period and cultivation conditions (including initial algal inoculum concentration, working volume, light/dark cycle, temperature, $\mathrm{pH}$ and $\mathrm{CO}_{2}$ concentration (Yang et al. 2016). In general, the findings of this study are shown a promising result to combine AD brewery effluent treatment with biomass production for biofuel feedstocks in Ethiopia.

\section{Nutrient and COD removal by Scenedesmus sp. Nitrogen removal}

Nitrogen is essential for microalgae growth as it contributes to the formation of proteins that are composed of amino acid chains linked by peptide bonds. Microalgae contain 5-10\% nitrogen (Lee and Lee 2001; Mata et al. 2012) and are able to assimilate nitrogen nutrients in the form of $\mathrm{NH}_{4}{ }^{+}-\mathrm{N}, \mathrm{NO}_{3}{ }^{-}-\mathrm{N}, \mathrm{NO}_{2}{ }^{-}-\mathrm{N}$ and urea.
But $\mathrm{NH}_{4}{ }^{+}-\mathrm{N}$ is the preferred nitrogen source (Delgadillo-Mirquez et al. 2016). The reductions of $\mathrm{NH}_{4}{ }^{+}-\mathrm{N}$ concentrations with its removal efficiencies with time in each season during the 18 days batch treatment depicts in Fig. 2a, b. The $\mathrm{NH}_{4}{ }^{+}-\mathrm{N}$ concentrations in all seasons shown a remarkable decrease in the first 10 days of treatment, later on, the reductions were slowed down and stable until the end of the experiments. The final concentrations of $\mathrm{NH}_{4}{ }^{+}-\mathrm{N}$ reached below $0.1 \mathrm{mg} \mathrm{L}^{-1}$ in all seasons of treatment. The removal efficiencies of $\mathrm{NH}_{4}{ }^{+}-\mathrm{N}$ were gradually increased and reached around 90\% from day 10 until the end of the experiments in all seasons. Finally, the removal efficiencies of $\mathrm{NH}_{4}{ }^{+}-\mathrm{N}$ by Scenedesmus sp. were found to around $99 \%$ in all seasons of treatment. However, over $50 \%$ of $\mathrm{NH}_{4}{ }^{+}-\mathrm{N}$ removals achieved by indigenous Scenedesmus sp. within the first six days of cultivation in all seasons, which met the permissible discharge limit recommended by EEPA (2003). The removal efficiencies of $\mathrm{NH}_{4}{ }^{+}-\mathrm{N}$ obtained by Scenedesmus sp. was better compared to those in other studies. For instance, Ferreira et al. (2017) studied the $\mathrm{NH}_{4}{ }^{+}-\mathrm{N}$ removal efficiencies of Scenedesmus obliquus in brewery effluent and reported the highest removal of $91 \%$. Ansari et al. (2017b) reported a maximum removal of $88.7 \% \mathrm{NH}_{4}{ }^{+}-\mathrm{N}$ by Scenedesmus obliquus grown in aquaculture wastewater. The differences in $\mathrm{NH}_{4}{ }^{+}-\mathrm{N}$ removal might be due to microalgae assimilation was not the sole mechanism, but $\mathrm{NH}_{4}{ }^{+}-\mathrm{N}$ striping at high $\mathrm{pH}$ (Li et al. 2011) may contribute to the removal of $\mathrm{NH}_{4}{ }^{+}-\mathrm{N}$. The $\mathrm{pH}$ reached over 9 in this study during indigenous microalgae cultivation. Therefore, this might have contributed to higher removal efficiency. 

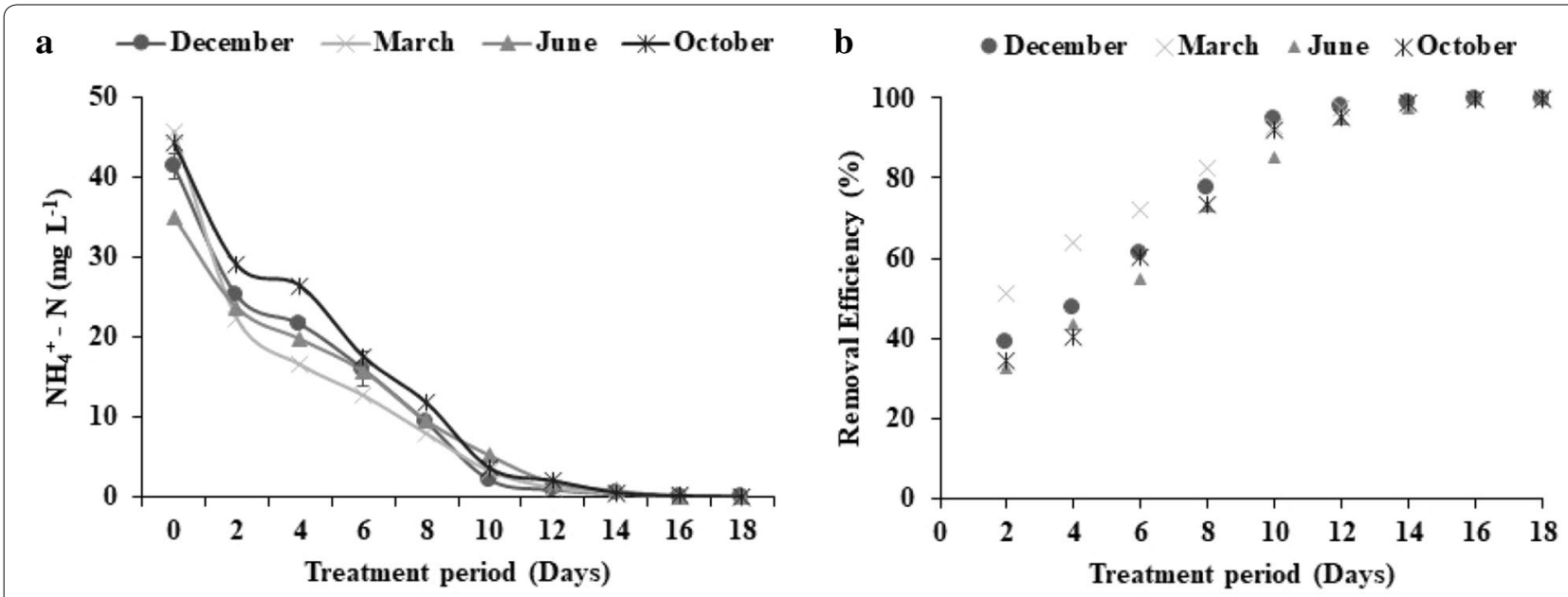

Fig. 2 Variation of concentration (a) and removal efficiencies (b) of $\mathrm{NH}_{4}{ }^{+}-\mathrm{N}$ during experiment of each season

Figure $3 \mathrm{a}$, b shows the variation of TN concentrations with its removal efficiencies during the experimental period in all seasons. The TN concentrations gradually decreased along with increasing removal efficiencies over time in all seasons. The final concentrations were found to be $3.27 \pm 0.21,2.33 \pm 0.06,3.33 \pm 0.25$ and $2.87 \pm 0.45 \mathrm{mg} \mathrm{L}^{-11}$ with removal efficiencies of $94.03 \%$, 95.95\%, 92.48\%, and 94.97\% in December, March, June and October, respectively. However, the removal efficiencies of TN reached over $60 \%$ with its concentration below $20 \mathrm{mg} \mathrm{L}^{-1}$ in 8 days of treatment in each season, which met the permissible discharge limit of the brewery effluent standard of Ethiopia. Therefore, the utilization of indigenous Scenedesmus sp. for the removal of nitrogen nutrients from AD brewery effluent is very crucial to protect the deterioration of surface water bodies and reduces the cost and energy demands for wastewater treatment in Ethiopia. The TN removal efficiencies of indigenous Scenedesmus sp. in this study were comparable to those in other studies. For example, Darpito et al. (2014) studied the nutrient removal efficiency of microalgae Chlorella protothecoides in anaerobically digested brewery effluent. They reported that the highest total nitrogen removal efficiency was more than $90 \%$, with an initial $72.6 \mathrm{mg} \mathrm{L}^{-1}$ TN. Farooq et al. (2013) also found that a TN removal efficiency of $90 \%$ using Chlorella vulgaris during the first stage of the two-stage photoautotrophic-photoheterotrophic cultivation system in brewery effluent. But TN removal of this study was higher than those reported in other studies of Choi (2016) and Marchão et al. (2018), where a maximum removal of $83.74 \%$ and $76 \%$ was achieved in brewery effluent, respectively.
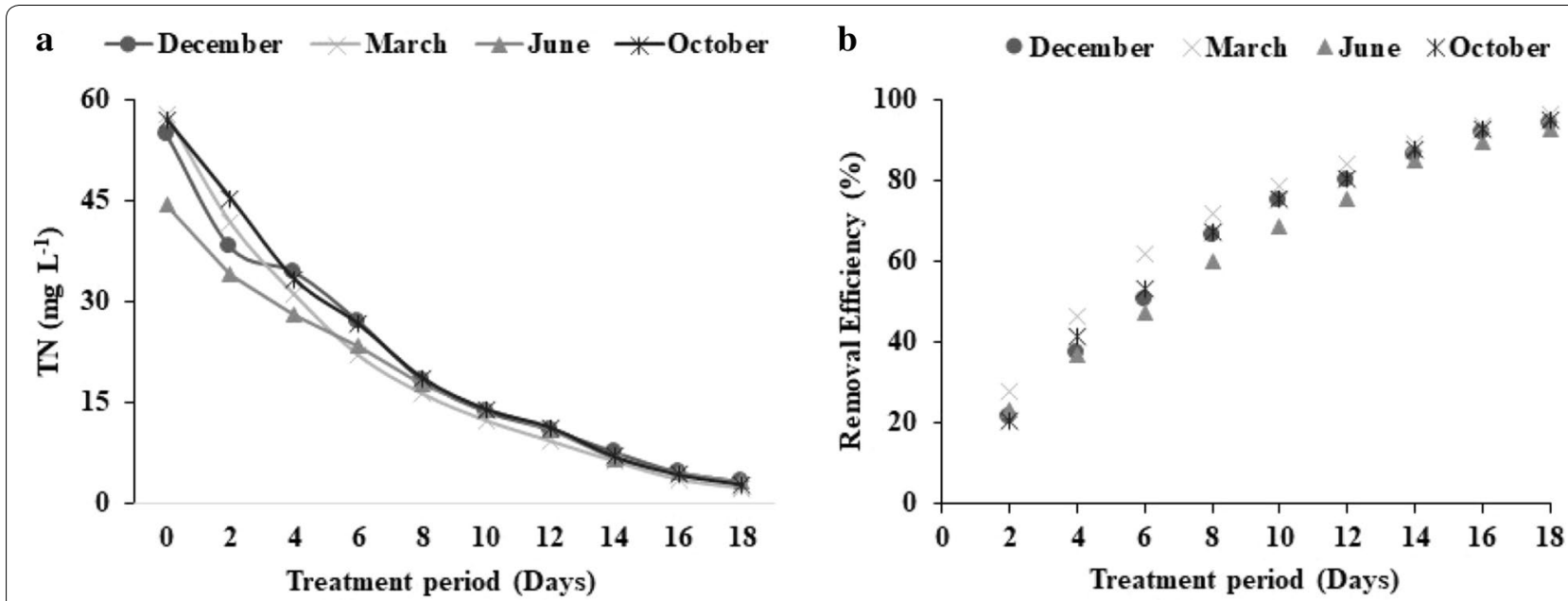

Fig. 3 Change of concentration (a) removal efficiencies (b) of TN over the experimental periods of each season 


\section{Phosphorus removal}

Phosphorus is another essential macronutrient that has an influence on algae growth and is about 0.5$3.3 \%$ in algal biomass (Subramaniyam et al. 2016). It is assimilated by microalgae as inorganic orthophosphate through an active process that requires energy (Rasoul-amini et al. 2014; Chaudhary et al. 2017). The change of concentrations with uptake efficiencies of $\mathrm{PO}_{4}{ }^{3-}-\mathrm{P}$ and TP over time in each season displays in Figs. 4a, b and $5 \mathrm{a}, \mathrm{b}$, respectively. The concentrations of $\mathrm{PO}_{4}{ }^{3-}-\mathrm{P}$ and $\mathrm{TP}$ steadily decreased along with the increase of removal efficiencies in all seasons of treatment. The concentrations of $\mathrm{PO}_{4}{ }^{3-}-\mathrm{P}$ were found to be $13.91 \pm 0.04,12.51 \pm 0.46,11.39 \pm 0.81$, and $12.53 \pm 0.37 \mathrm{mg} \mathrm{L}^{-1}$ with removal efficiencies of $63.45 \%, 69.72 \%, 67.75 \%$, and $65.59 \%$ in December,
March, June, and October at the end of the experiment, respectively. The TP concentrations were also found to be to $17.13 \pm 0.65,14.54 \pm 0.73,15.03 \pm 0.70$ and $14.47 \pm 0.69 \mathrm{mg} \mathrm{L}^{-1}$ with removal efficiencies of $65.28 \%, 72.81 \%, 69.88 \%$, and $69.32 \%$ in December, March, June, and October at the end of experiments, respectively. The phosphorus nutrient concentrations obtained at the end of cultivation were found to be above the permissible discharge limit for brewery effluent standard recommended by EEPA (2003).The phosphorus removal efficiencies obtained in this study were lower than those attained by Farooq et al. (2013), Darpito et al. (2014), and Subramaniyam et al. (2016), who reported a maximum removal of $80 \%, 90 \%$, and $100 \%$ from brewery effluent using Chlorella vulgaris, Chlorella prototheocides and Chlorella sp., respectively,
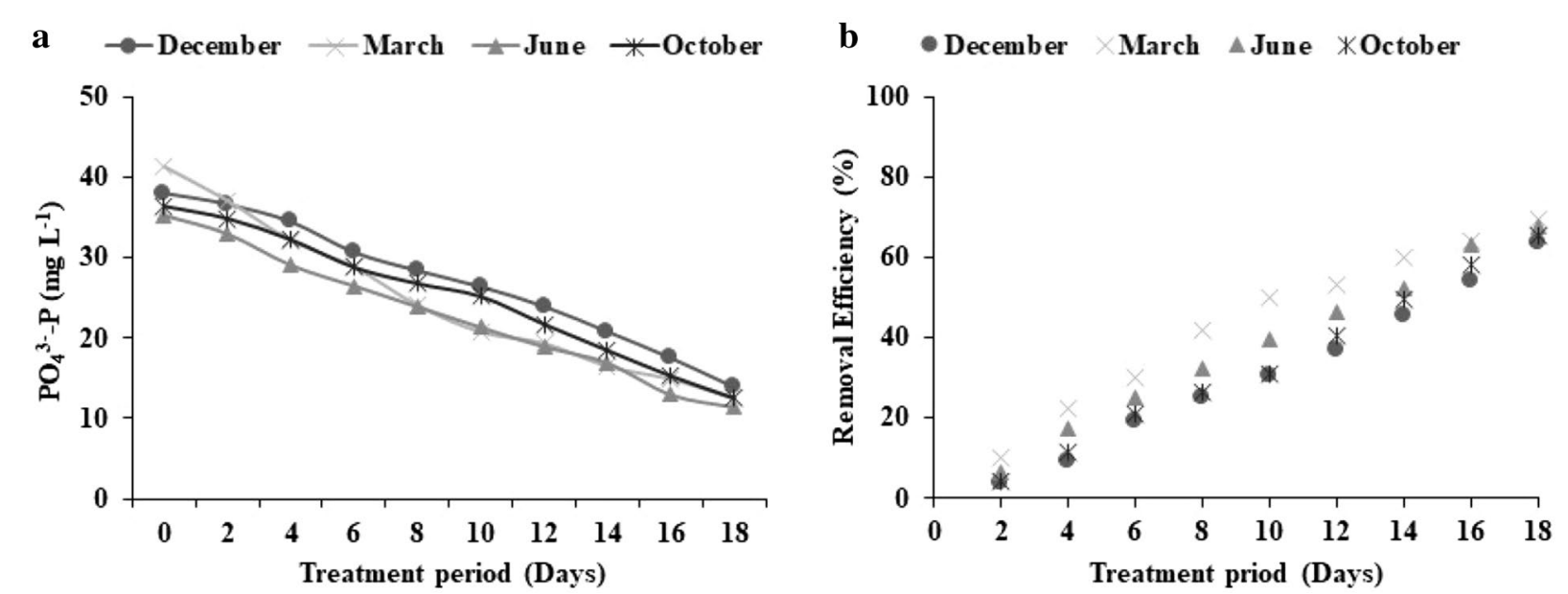

Fig. 4 Change of concentration (a) removal efficiencies (b) of $\mathrm{PO}_{4}{ }^{3-}$ - $\mathrm{P}$ over the experimental periods of each season
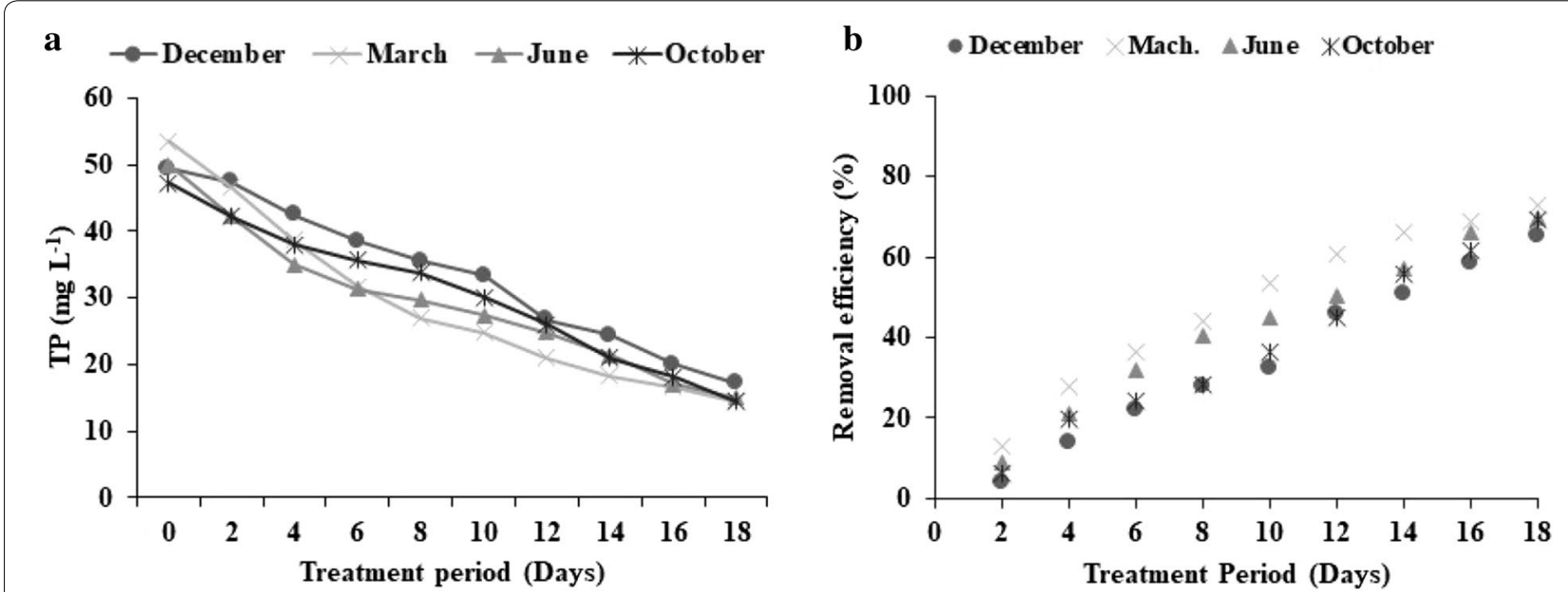

Fig. 5 Change of concentration (a) removal efficiencies (b) of TP over the experimental periods of each season 
but higher than those obtained by Ferreira et al. (2017), Choi (2016), and Marchão et al. (2018), who reported $40 \%, 43 \%$, and $54.67 \%$ TP removals from brewery effluent, respectively. The TP removal efficiencies in this study were comparable with those obtained by Raposo et al. (2010), who attained a maximum of 66\% TP from brewery effluent using Chlorella vulgaris.

The differences in phosphorus removal among various studies might be due to the uptake of phosphorus by microalgae is affected by algal physiology, initial phosphate concentration, and chemical form of available phosphate, light intensity, $\mathrm{pH}$, and temperature (Gupta et al. 2016). Choi and Lee (2014) also shown that removal of TN depends on the N/P ratio, which affects biomass growth and, $\mathrm{N}$ and $\mathrm{P}$ nutrients removal in wastewater. Xin et al. (2010) reported that the optimal N/P ratio for growth of Scenedesmus sp. was in the range 5:1-12:1. In this study, the N/P ratio varied from 1:0.89 to $1: 1.21$, which indicated the AD brewery effluent as nitrogen limitation. Since the removal of phosphorus associated with $\mathrm{N}$ removal, the limitation of nitrogen in a brewery effluent has contributed to low uptake of phosphorus into biomass irrespective of the $P$ concentrations in the effluent (Whitton et al. 2016). Therefore, the removal of phosphorus by indigenous microalgae form $\mathrm{AD}$ brewery effluent maybe improve by mixing $\mathrm{AD}$ brewery effluent with nitrogen-rich wastewater.

\section{COD removal}

Carbon is an important element found in algal biomass, and it constitutes over $50 \%$ in typical algal biomass (Mata et al. 2012). Microalgae cannot metabolize all the organic sources. Simple organic carbon sources such as acetate and glucose are usually preferred by microalgae (Lee and Lee 2001). COD concentration reduction with its uptake efficiencies over the experimental periods of each season are shown in Fig. 6a, b. COD concentration reduction with an increase of its removal efficiencies remarkably observed until day 6 in December, day 12 in March and day 8 in June and October. However, the COD concentrations after these days of each month were becoming first increased and then dropped. At the end of cultivation, the COD concentrations obtained were $87 \pm 8.54$, $79.33 \pm 11.06,88.33 \pm 9.07$, and $101.33 \pm 3.51 \mathrm{mg} \mathrm{L}^{-1}$ with removal efficiencies of $76.48 \%, 81.92 \%, 77.28 \%$, and $74.63 \%$ in December, March, June and October, respectively. But, the indigenous Scenedesmus sp. was able to reduce COD concentrations below the permissible discharge limit of the brewery standard within the first four days of treatment. On the other hand, as the treatment period increased, it was observed that the increase in COD concentrations. This could be due to microalgae are released organic compounds in the culture instead of taking up. Similar results regarding COD concentration increasing were observed by Wang et al. (2010) and Yuan et al. (2012), who had grown Chlorella vulgaris in municipal wastewater and centrate, respectively. The decreasing of COD concentration in the culture was due to that the microalgae could use organic carbon for their cell growth in addition to $\mathrm{CO}_{2}$ (Wang et al. 2012; Ding et al. 2015). As a result, the indigenous Scenedesmus sp. can utilize organic matter for their growth so that this provides an option and an alternative to remove organic matter from AD brewery effluent using this microalga. Even though COD removal efficiency by indigenous Scenedesmus sp. in this study was met the discharge limit of the country, it was lower when compared to that in the previous studies.
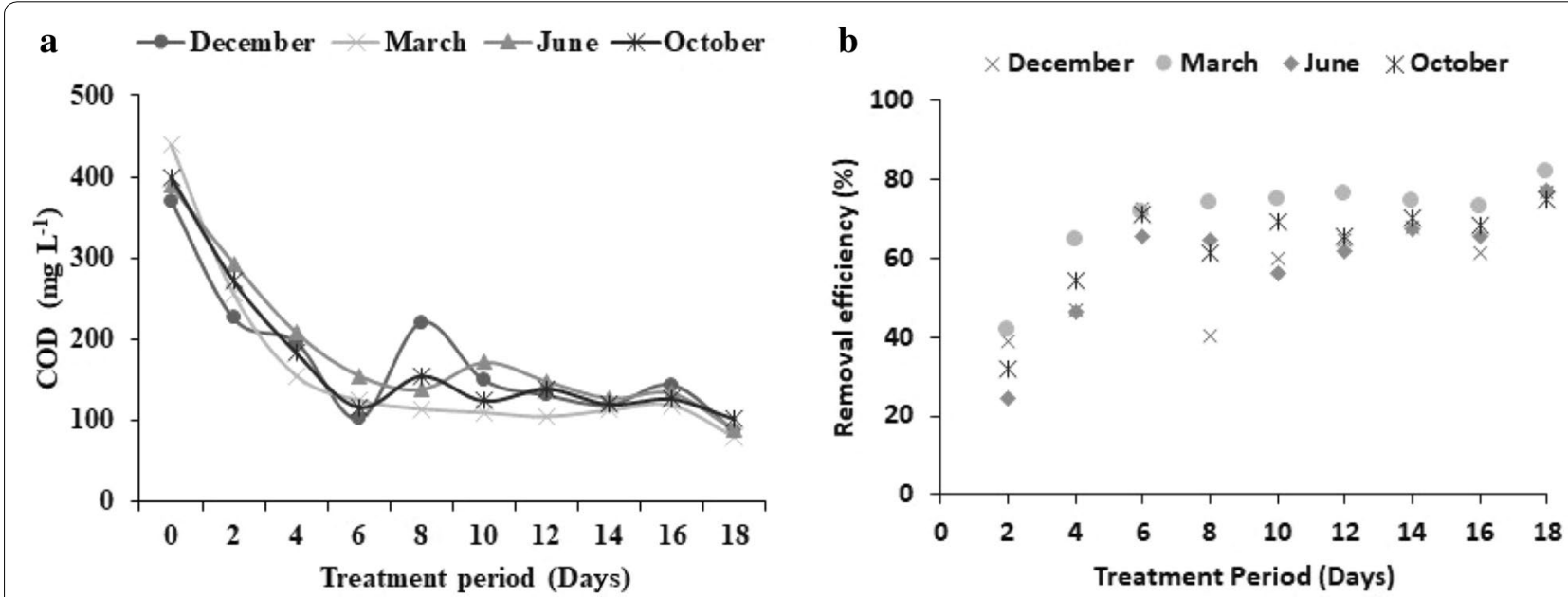

Fig. 6 Profile of COD concentrations (a) and uptake efficiencies (b) over the experimental period 
For example, Ansari et al. (2017a), Ma et al. (2017) and Tripathi et al. (2019) were achieved the COD removal efficiency of $95 \%, 87.2 \%$, and $88.2 \%$ by Scenedesmus sp. in institutional, molasses, and municipal wastewater, respectively. However, the COD removal efficiencies in this study were higher than those reported by Raposo et al. (2010) and Ferreira et al. (2017), who found a maximum of $15 \%$ and $61.9 \%$ by Scenedesmus obliquus and Chlorella vulgaris in brewery wastewater, respectively.

\section{Carbohydrate/total sugar/extraction Effect of pretreatments}

The biomass obtained after the treatment of brewery in this study effluent used for the extraction of carbohydrate. Microalgae contain carbohydrates which found in their cell well with no lignin and hemicellulose, and starch inside their cell. Both these starch and cellulose can easily be converted into fermentable sugar, utilizing for bioethanol production (Ho et al. 2013). The pretreatment methods like autoclave, microwave and oven heating along with acids or bases were performed in this study for the extraction of carbohydrates that are further processing for bioethanol production. Figure 7 depicts the effect of the pretreatment methods with acid or base hydrolytic agents on carbohydrate extraction. Results showed that microwave pretreatment with all hydrolytic agents provided a higher carbohydrate /total sugar/ from indigenous Scenedesmus sp. as compared to the other two pretreatments. Regarding the acid or base hydrolytic agents, the acid $\mathrm{HCl}$ produced a higher carbohydrate /total sugar/ compared with the other hydrolytic agents in all pretreatments. The highest value of total sugar obtained in microwave pretreatment was $207.70 \mathrm{mg} \mathrm{g}^{-1}$, which was significantly different $(\mathrm{P}<0.05)$ compared to that obtained using autoclave and oven pretreatments. On the other hand, alkaline hydrolysis either $\mathrm{NaOH}$ or $\mathrm{KOH}$ produced a very low carbohydrate /total sugar/ compared to acid hydrolysis in all pretreatments. Generally, it is possible to conclude that the types of pretreatment and hydrolytic agents determine carbohydrate extraction from microalgae biomass obtained after wastewater treatment. The higher efficiency of microwave-assisted hydrolysis to produce total sugar might be the fact that microwave-assisted hydrolysis uses a noncontact heat that can penetrate into biomass, interact with polar molecule like water in biomass and heat the whole sample uniformly (Mubarak et al. 2015).

Different pretreatment for microalgal biomass were employed to extract carbohydrates in the previous studies. For example, Hernández et al. (2015) used a microwave and an autoclaved pretreatments for cell disruption of Scenedesmus almeriensis grown on mineral

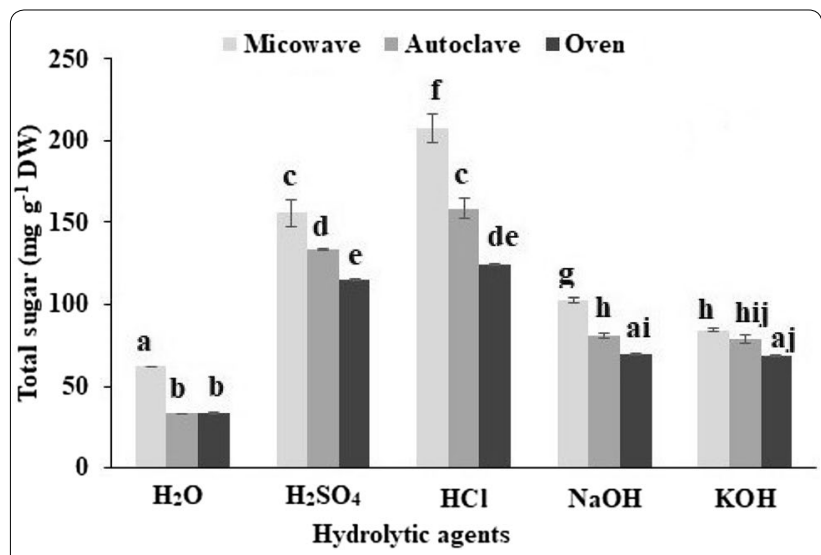

Fig. 7 Total sugar content in Scenedesmus sp. using a microwave, b autoclave and $\mathbf{c}$ oven pretreatments. The means and standard deviations of the three replicates are indicated. ( $P<0.05$ for different letters)

medium. They reported a maximum of $88 \mathrm{mg} \mathrm{g}^{-1}$ total sugar using autoclave with the hydrolytic agent $\mathrm{H}_{2} \mathrm{SO}_{4}$. Miranda et al. (2012) employed four pretreatments (sonication, bead beating, autoclaving, and homogenization) for cell disruption of Scenedesmus obliquus grown in Bristol medium to produce sugar. They reported that a maximum of $8.2 \% \mathrm{~g} \mathrm{eq}_{\mathrm{glu}} \mathrm{g} \mathrm{dw}^{-1}$ carbohydrates was achieved in autoclave pretreatment using $\mathrm{H}_{2} \mathrm{SO}_{4}$. Harun et al. (2011) also performed alkaline pretreatment in the oven heating with $0.75 \%(\mathrm{w} / \mathrm{v})$ of $\mathrm{NaOH}$ at $120{ }^{\circ} \mathrm{C}$ for $30 \mathrm{~min}$ for Chlorococcum infusionum, and they reported a maximum carbohydrate/total sugar/ of $350 \mathrm{mg} \mathrm{g}^{-1}$. The variation in carbohydrate/total sugar/ released from microalgae in different studies might be the attribution of several factors which are the microalgae species type and growth conditions like the availability of nutrient, temperature, illumination, light-dark cycle, and growth phase (Khan et al. 2018).

\section{Effect of acid concentrations and microwave hydrolysis time}

Acid concentrations are major functioning parameter that can affect the hydrolysis of microalgae biomass. Figure 8a shows the effects of acid concentrations on the production of total sugar using $5 \%(\mathrm{w} / \mathrm{v})$ microalgae biomass and microwave at 1000 watts and $120^{\circ} \mathrm{C}$ for $15 \mathrm{~min}$. The maximum total sugar obtained was $207.70 \mathrm{mg} \mathrm{g}^{-1}$ with $3 \mathrm{~N} \mathrm{HCl}$. But beyond this concentration the releasing sugar decreased. Furthermore, the carbohydrate production using $3 \mathrm{~N} \mathrm{HCl}$ was significantly different $(\mathrm{P}<0.05)$ compared with the other concentrations of $\mathrm{HCl}$. The finding of this study with regard to decreasing of total sugar released as increasing concentration was similar to those reported by Miranda et al. (2012). They obtained that the releasing 

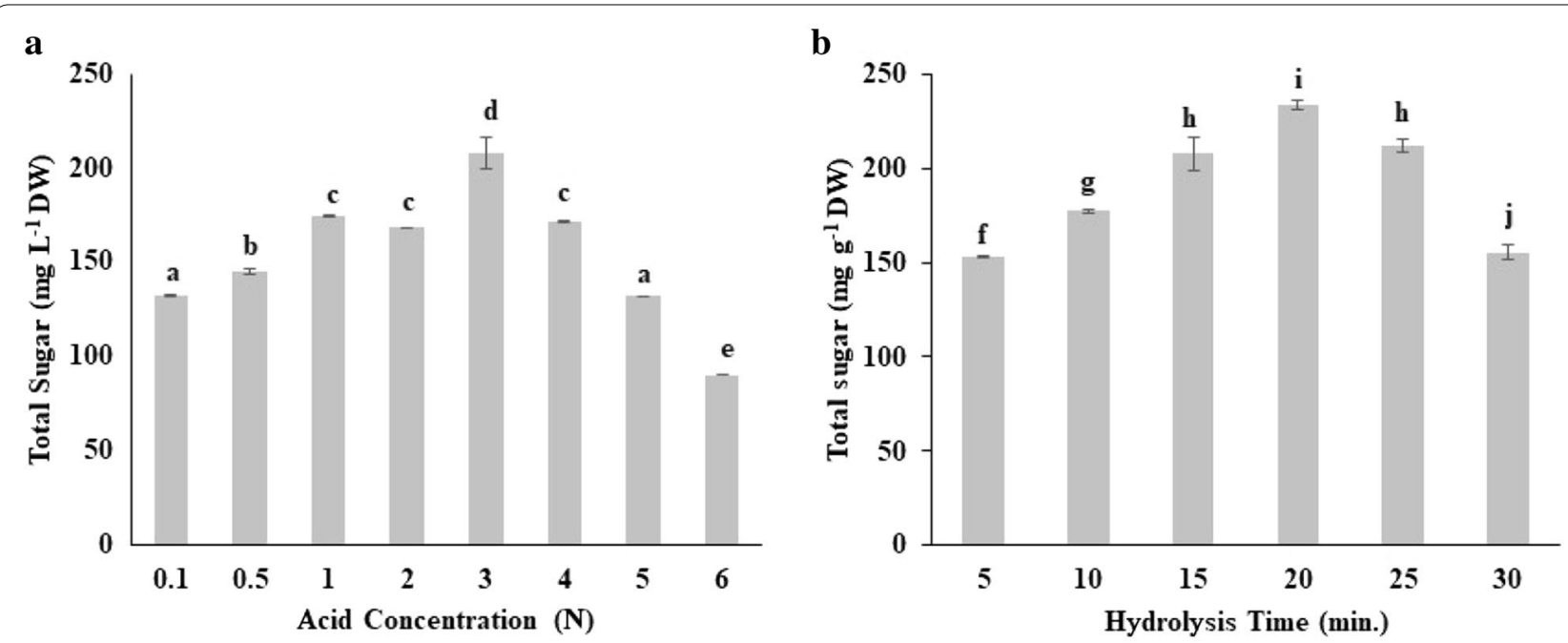

Fig. 8 Effect of $\mathbf{a}$ acid concentrations, $\mathbf{b}$ microwave hydrolysis time on extraction of total sugar. The means and standard deviations of the three replicates are indicated. ( $P<0.05$ for different letters)

of sugar became decrease when the microalgae Scenedesmus obliquus was hydrolyzed with $\mathrm{H}_{2} \mathrm{SO}_{4}$ in an autoclave with a concentration above $2 \mathrm{~N}$. The decreasing of sugar content with an increase of acid concentration attributed due to the degradation of monosaccharide into sugar degradation products like furfural (Boonmanumsin et al. 2012; Khan et al. 2017).

Figure $8 \mathrm{~b}$ shows the effect of hydrolysis time on the releasing of total sugar from $5 \%(\mathrm{w} / \mathrm{v})$ microalgae biomass using $3 \mathrm{~N} \mathrm{HCl}$ at 1000 watts and $120{ }^{\circ} \mathrm{C}$. The maximum total sugar obtained from biomass of Scenedesmus sp. during the $20 \mathrm{~min}$ of microwave hydrolysis time was $233.89 \mathrm{mg} \mathrm{g}^{-1} \mathrm{DW}$, which was significantly different $(\mathrm{P}<0.05)$ compared to other microwave hydrolysis time. The total sugar production was decreased as a microwave hydrolysis time above $20 \mathrm{~min}$, which may be due to the occurrence of the decomposition of sugar to inhibitory compounds such as furfural and hydroxylmethylfurfural (Boonmanumsin et al. 2012). Hernández et al. (2015) also studied the effect of autoclave time $(30,45,60$, and $90 \mathrm{~min})$ on total sugar releasing from microalgae, including Scenedesmus almeriensis, and they observed the increase of sugar release from 53 to $88 \mathrm{mg} \mathrm{g}^{-1}$ as the time goes from 30 to $60 \mathrm{~min}$. This confirms that the variation of time has an effect on the production of total sugar. But the microwave pretreatment in this study was performed with a shorter time with a higher amount of total sugar when compared to an autoclave used by Hernández et al. (2015).

\section{Conclusion}

This study has shown that the indigenous microalgae, Scenedesmus sp. had a promising approach in the treatment of brewery effluent and carbohydrate production. The results showed that the indigenous Scenedesmus sp. efficiently remove nitrogen and COD from the brewery effluent, achieving a permissible discharge limit for brewery effluent standard. But the removal of phosphorus nutrients did not meet the permissible discharge limit for brewery effluent standard. Concerning the carbohydrate extraction, microwave-assisted acid hydrolysis showed a higher performance than autoclave and oven heating. Moreover, microwave-assisted acid hydrolysis produced a higher result than that of microwave-assisted alkaline hydrolysis. Acid concentration and hydrolysis times had effects on carbohydrate extraction using microwaveassisted acid hydrolysis. The $\mathrm{HCl}$ with a concentration of $3 \mathrm{M}$ resulted in a higher total sugar production compared with the other acid concentrations. Total sugar extraction with $3 \mathrm{~N} \mathrm{HCl}$ was a significant difference $(\mathrm{P}<0.05)$ with the other acid concentrations. The highest total sugar obtained in this study was $233.89 \mathrm{mg} \mathrm{g}^{-1}$ by using $5 \%(\mathrm{w} / \mathrm{v})$ biomass and $3 \mathrm{~N} \mathrm{HCl}$ at 1000 watts and $120{ }^{\circ} \mathrm{C}$ for $20 \mathrm{~min}$. Finally, the biomass obtained after brewery effluent treatment should be used for different purposes in addition to carbohydrate production to make the wastewater treatment based indigenous microalgae more sustainable. 


\section{Abbreviations}

AD: Anaerobic digested; DW: Dry weight; UASB: Up flow anaerobic sludge Blanket; COD: Chemical oxygen demand; TN: Total nitrogen; TN: Total phosphorus; EEPA: Ethiopian Environmental protection Authority.

\section{Acknowledgments}

This research was supported by the Center for Environmental Science of Addis Ababa University and Wolaita-Sodo University. The Authors of this paper wish to thanks BGI Ethiopia for accessing UASB effluent from their wastewater treatment plant.

\section{Authors' contributions}

MMK isolated and identified Scenedesmus sp. ZY conducted the experiments and carried out nutrient analysis and carbohydrate determination. SL and AH designed the experiments and supervised overall research activities. ZY wrote the draft of the manuscript. All authors read and approved the final manuscript.

\section{Funding}

Not applicable.

\section{Availability of data and materials}

The data sets used in this study are available from the corresponding author on reasonable request.

\section{Ethical approval and consent to participate}

Not applicable.

\section{Consent for publication}

Not applicable.

\section{Competing interests}

The authors declare that no conflict of interest.

\section{Author details}

${ }^{1}$ Department of Environmental Science, Wolaita Sodo University, Wolaita Sodo, Ethiopia. ${ }^{2}$ Center of Environmental Science, Addis Ababa University, Addis Ababa, Ethiopia.

Received: 4 September 2020 Accepted: 13 November 2020 Published online: 04 December 2020

\section{References}

Akunna JC (2015) 19-Anaerobic treatment of brewery wastes. Woodhead Publishing, Sawston

Alvarado-Lassman A, Rustrian E, Garcia-Alvarado MA, Rodriguez-Jimenez GC, Houbron E (2008) Brewery wastewater treatment using anaerobic inverse fluidized bed reactors. Bioresour Technol 99:3009-3015. https://doi. org/10.1016/j.biortech.2007.06.022

Andersen RA, Kawachi M (2005) Traditional microalgae isolation techniques. In: Andersen RA (ed) Algal culturing techniques. Elsevier/Academic Press, London, pp 83-100

Ansari AA, Khoja AH, Nawar A, Qayyum M (2017a) Wastewater treatment by local microalgae strains for $\mathrm{CO}_{2}$ sequestration and biofuel production. Appl Water Sci 7:4151-4158. https://doi.org/10.1007/s13201-017-0574-9

Ansari FA, Singh P, Guldhe A, Bux F (2017b) Microalgal cultivation using aquaculture wastewater: integrated biomass generation and nutrient remediation. Algal 21:169-177. https://doi.org/10.1016/j.algal.2016.11.015

APHA (1999) Standard methods for the examination of water and wastewater part 1000 standard methods for the examination of water and wastewater, 20th edn. Berlin, Washington

Arbib Z, Garrido-pe C (2013) Capability of different microalgae species for phytoremediation processes: wastewater tertiary treatment, $\mathrm{CO}_{2}$ biofixation and low cost biofuels production. Water Res 49:465-474. https:// doi.org/10.1016/j.watres.2013.10.036

Baloch MI, Akunna JC, Collier PJ (2007) The performance of a phase separated granular bed bioreactor treating brewery wastewater. Biores Technol 98:1849-1855. https://doi.org/10.1016/j.biortech.2006.06.014
Bellinger EG, Sigee DC (2010) Freshwater algae: identification and use as bioindicators Edward. Wiley, New York

Boonmanumsin P, Treeboobpha S, Jeamjumnunja K, Luengnaruemitchai A, Chaisuwan T, Wongkasemjit S (2012) Release of monomeric sugars from Miscanthus sinensis by microwave-assisted ammonia and phosphoric acid treatments. Biores Technol 103:425-431. https://doi.org/10.1016/j. biortech.2011.09.136

Cai T, Park SY, Li Y (2013) Nutrient recovery from wastewater streams by microalgae : Status and prospects. Renew Sustain Energy Rev 19:360-369. https://doi.org/10.1016/j.rser.2012.11.030

Chaudhary R, Tong YW, Dikshit AK (2017) CO 2 -assisted removal of nutrients from municipal wastewater by microalgae Chlorella vulgaris and Scened esmus obliquus. Int J Environ Sci Technol. https://doi.org/10.1007/s1376 2-017-1571-0

Choi H (2016) Parametric study of brewery wastewater effluent treatment using Chlorella vulgaris microalgae. Environ Eng Res 1:25

Choi HJ, Lee SM (2014) Effect of the N/P ratio on biomass productivity and nutrient removal from municipal wastewater. Bioprocess Biosyst Eng. https://doi.org/10.1007/s00449-014-1317-z

Costa JAV, Freitas BCB, Moraes L, Zaparoli M, Morais MG (2020) Progress in the physicochemical treatment of microalgae biomass for value- added product recovery. Biores Technol 301:122727. https://doi.org/10.1016/j. biortech.2019.122727

Darpito C, Shin WS, Jeon S, Lee H, Nam K, Kwwon JH, Yang JW (2014) Cultivation of Chlorella protothecoides in anaerobically treated brewery wastewater for cost-effective biodiesel production. Bioprocess Biosyst Eng 38(3):523-530. https://doi.org/10.1007/s00449-014-1292-1294

Delgadillo-Mirquez L, Lopes F, Taidi B, Pareau D (2016) Nitrogen and phosphate removal from wastewater with a mixed microalgae and bacteria culture. Biotechnology Reports 11:18-26

Delrue F, Álvarez-Díaz PD, Fon-Sing S, Fleury G, Sassi JF (2016) The environmental biorefinery: using microalgae to remediate wastewater, a win. Environ Bioref. https://doi.org/10.3390/en9030132

Dickinson KE, Whitney CG, Mcginn PJ (2013) Nutrient remediation rates in municipal wastewater and their effect on biochemical composition of the microalga Scenedesmus sp. AMDD. Algal 2:127-134. https://doi. org/10.1016/j.algal.2013.01.009

Ding J, Zhao F, Cao Y, Xing L, Liu W, Mei S, Ding J, Zhao F, Cao Y, Xing LI, Liu WEI, Mei S, Li S (2015) Cultivation of microalgae in dairy farm wastewater without sterilization cultivation of microalgae in dairy farm wastewater without sterilization. Int J Phytoremed 17:222-227. https://doi. org/10.1080/15226514.2013.876970

Dubois M, Gilles KA, Hamilton JK, Rebers PA, Smith F (1956) Colorimetric method for determination of sugars and relatedsubstances. Anal Chem 28(3):350-356

EEPA (2003) Environmental standards for industrial pollution control in Ethiopia. Environmnetal Protection Authority, Ethiopia

Farooq W, Lee Y, Ryu B, Kim B, Kim H, Choi Y, Yang J (2013) Two-stage cultivation of two Chlorella sp. strains by simultaneous treatment of brewery wastewater and maximizing lipid productivity. Bioresour Technol 132:230-238. https://doi.org/10.1016/j.biortech.2013.01.034

Ferreira A, Ribeiro B, Marques PASS, Ferreira AF, Paula A, Pinheiro HM, Reis A, Gouveia L (2017) Scenedesmus obliquus mediated brewery wastewater remediation and $\mathrm{CO}_{2}$ bio fixation for green energy purposes. J Clean Prod 165:1316-1327. https://doi.org/10.1016/j.jclepro.2017.07.232

Gupta PL, Choi HJ, Lee S (2016) Enhanced nutrient removal from municipal wastewater assisted by mixotrophic microalgal cultivation using glycerol. Environ Sci Pollut Res 23:10114-10123. https://doi.org/10.1007/s1135 6-016-6224-1

HACH. (2002). Model DR/2400 Spectrophotometer. Hach Company, USA.

Harun R, Jason WSY, Cherrington T, Danquah MK (2011) Exploring alkaline pretreatment of microalgal biomass for bioethanol production. Appl Energy 88(10):3464-3467. https://doi.org/10.1016/j.apenergy.2010.10.048

Hernández D, Riaño B, Coca M, García-gonzález MC (2015) Saccharification of carbohydrates in microalgal biomass by physical, chemical and enzymatic pre-treatments as a previous step for bioethanol production. Chem Eng J 262:939-945. https://doi.org/10.1016/j.cej.2014.10.049

Ho S, Huang S, Chen C, Hasunuma T, Kondo A (2013) Bioethanol production using carbohydrate-rich microalgae biomass as feedstock. Biores Technol 135:191-198. https://doi.org/10.1016/j.biortech.2012.10.015 
Hoffmann JP (1998) Wastewater treatment with suspended and nonsuspended algae. J Phycol 34:757-763

Hu X, Meneses YE, Stratton J, Wang B (2019) Acclimation of consortium of micro-algae help removal of organic pollutants from meat processing wastewater. J Clean Prod 214:95-102. https://doi.org/10.1016/j.jclep ro.2018.12.255

Kassim MA, Bhattacharya S (2016) Dilute alkaline pretreatment for reducing sugar production from Tetraselmis suecica and Chlorella sp. biomass. Process Biochem 51:1757-1766

Khan MI, Lee MG, Shin JH, Kim JD (2017). Pretreatment optimization of the biomass of Microcystis aeruginosa for efficient bioethanol production. AMB Express. https://doi.org/10.1186/s13568-016-0320-y

Khan MI, Shin JH, Kim JD (2018) The promising future of microalgae: current status, challenges, and optimization of a sustainable and renewable industry for biofuels, feed, and other products. Microb Cell Fact 17:1-21. https://doi.org/10.1186/s12934-018-0879-x

Kwon G, Nam J, Kim D, Song C, Jahng D (2020) Growth and nutrient removal of Chlorella vulgaris in ammonia-reduced raw and anaerobically-digested piggery wastewaters. Environ Eng Res 25(2):135-146

Lee K, Lee C (2001) Effect of light/dark cycles on wastewater treatments by microalgae cell growth under different light conditions. Biotechnol Bioprocess Eng 6:194-199

Lee Y, Chen W, Shen H, Han D, Li Y, Jones HDT, Timlin JA, Hu Q (2013) Basic culturing and analytical measurement techniques. In: Richmond A, Hu Q (eds) Handbook of microalgal culture: applied phycology and biotechnology. Blackwell Publishing Ltd, New York, pp 37-68

Li Y, Chen Y, Chen P, Min M, Zhou W, Martinez B, Zhu J, Ruan R (2011) Characterization of a microalga Chlorella sp. well adapted to highly concentrated municipal wastewater for nutrient removal and biodiesel production. Biores Technol 102:5138-5144. https://doi.org/10.1016/j.biort ech.2011.01.091

Li Y-r, Tsai W, Hsu Y, Xie M, Chen J (2014) Comparison of autotrophic and mixotrophic cultivation of green microalgal for biodiesel production. Energy Procedia 52:371-376. https://doi.org/10.1016/j.egypro.2014.07.088

Ma C, Wen H, Xing D, Pei X, Zhu J, Ren N, Liu B (2017) Biotechnology for Biofuels Molasses wastewater treatment and lipid production at low temperature conditions by a microalgal mutant Scenedesmus. Biotechnol Biofuels 10(111):1-13. https://doi.org/10.1186/s13068-017-0797-x

Marchão L, da Silva TL, Gouveia L, Reis A (2018) Microalgae-mediated brewery wastewater treatment: effect of dilution rate on nutrient removal rates, biomass biochemical composition, and cell physiology. J Appl Phycol 30(3):1583-1595. https://doi.org/10.1007/s10811-017-1374-1

Martinez ME, Sanchez S, Jimenez JM, Yousfi F. El, Munoz L (2000) Nitrogen and phosphorus removal from urban wastewater by the microalga Scenedesmus obliquus. Bioresour Technol 20:73

Mata TM, Martins AA, Caetano NS (2010) Microalgae for biodiesel production and other applications: a review. Renew Sustain Energy Rev 14:217-232. https://doi.org/10.1016/j.rser.2009.07.020

Mata TM, Melo AC, Simões M, Caetano NS (2012) Bioresource Technology Parametric study of a brewery effluent treatment by microalgae Scenedesmus obliquus. Bioresour Technol 107:151-158. https://doi.org/10.1016/j.biort ech.2011.12.109

McGinn PJ, Dickinson KE, Bhatti S, Frigon J-C, Guiot SR, O'Leary SJB (2011) Integration of microalgae cultivation with industrial waste remediation for biofuel and bioenergy production : Opportunities and limitations Integration of microalgae cultivation with industrial waste remediation for biofuel and bioenergy production: opp. Photosynth Res. https://doi. org/10.1007/s11120-011-9638-0

Mcginn PJ, Dickinson KE, Park KC, Whitney CG, Macquarrie SP, Black FJ, Frigon J, Guiot SR, Leary SJBO (2012) Assessment of the bioenergy and bioremediation potentials of the microalga Scenedesmus sp. AMDD cultivated in municipal wastewater effluent in batch and continuous mode. Algal 1:155-165. https://doi.org/10.1016/j.algal.2012.05.001

Mennaa FZ, Arbib Z, Perales JA (2015) Urban wastewater treatment by seven species of microalgae and an algal bloom : biomass production, $\mathrm{N}$ and P removal kinetics and harvestability. Water Res 83:42-51. https://doi. org/10.1016/j.watres.2015.06.007

Miranda JR, Passarinho PC, Gouveia L (2012) Pre-treatment optimization of Scenedesmus obliquus microalga for bioethanol production. Bioresour Technol 104:342-348. https://doi.org/10.1016/j.biortech.2011.10.059
Mubarak M, Shaija A, Suchithra TV (2015) A review on the extraction of lipid from microalgae for biodiesel production. Algal 7:117-123. https://doi. org/10.1016/j.algal.2014.10.008

Nagi M, He M, Li D, Gebreluel T, Cheng B, Wang C (2020) Utilization of tannery wastewater for biofuel production: new insights on microalgae growth and biomass production. Sci Rep 10(1530):1-14. https://doi.org/10.1038/ s41598-019-57120-4

Nichols HW, Bold HC (1965) Trichosarcina polymorpha. J Phycol 1:34-38

Oliveira O, Gianesella S, Silva V, Mata T, Caetano N (2017) Lipid and carbohydrate profile of microalga isolated wastewater. Energy Procedia 136:468-473. https://doi.org/10.1016/j.egypro.2017.10.305

Phwan CK, Chew KW, Sebayang AH, Ong HC, Ling TC, Malek MA, Ho YC, Show PL (2019) Biotechnology for biofuels effects of acids pre-treatment on the microbial fermentation process for bioethanol production from microalgae. Biotechnol Biofuels 12(191):1-8. https://doi.org/10.1186/ s13068-019-1533-5

Raposo MFDJ, Oliveira SE, Castro PM, Bandarra NM, Morais RM, Brew JI (2010) On the utilization of microalgae for brewery effluent treatment and possible applications of the produced biomass. J Inst Brew 116(3):285-292

Rasoul-amini S, Montazeri-najafabady N, Shaker S, Safari A (2014) Biocatalysis and agricultural biotechnology removal of nitrogen and phosphorus from wastewater using microalgae free cells in bath culture system. Biocatal Agric Biotechnol 3:126-131. https://doi.org/10.1016/j. bcab.2013.09.003

Rawat I, Kumar RR, Mutanda T, Bux F (2011) Dual role of microalgae : Phycoremediation of domestic wastewater and biomass production for sustainable biofuels production. Appl Energy 88:3411-3424. https://doi. org/10.1016/j.apenergy.2010.11.025

Renuka N, Sood A, Ratha SK (2013) Evaluation of microalgal consortia for treatment of primary treated sewage effluent and biomass production. J Appl Phycol 12:1529-1537. https://doi.org/10.1007/s10811-013-9982-x

Ruiz-marin A, Mendoza-espinosa LG, Stephenson T (2010) Growth and nutrient removal in free and immobilized green algae in batch and semi-continuous cultures treating real wastewater. Bioresour Technol 101:58-64. https://doi.org/10.1016/j.biortech.2009.02.076

Ruiz-martinez A, Garcia NM, Romero I, Seco A, Ferrer J (2012) Microalgae cultivation in wastewater: nutrient removal from anaerobic membrane bioreactor effluent. Bioresour Technol 126:247-253. https://doi.org/10.1016/j. biortech.2012.09.022

Shubert E, Gärtner G (2015) Nonmotile coccoid and colonial green algae. In: Sheath RG, Kociolek JP (eds) Wehr JD. Elsevier Inc, Freshwater algae of North America. Iondon, pp 321-370

Sivaramakrishnan R, Incharoensakdi A (2018) Utilization of microalgae feedstock for concomitant production of bioethanol and biodiesel. Fuel 217:458-466. https://doi.org/10.1016/j.fuel.2017.12.119

Sturm BSM, Lamer SL (2011) An energy evaluation of coupling nutrient removal from wastewater with algal biomass production. Appl Energy 88(10):3499-3506. https://doi.org/10.1016/j.apenergy.2010.12.056

Subramaniyam V, Ramraj S, Ganeshkumar V (2016) Bioresource Technology Cultivation of Chlorella on brewery wastewater and nano-particle biosynthesis by its biomass. Bioresour Technol 211:698-703. https://doi. org/10.1016/j.biortech.2016.03.154

Tripathi R, Gupta A, Thakur IS (2019) An integrated approach for phycoremediation of wastewater and sustainable biodiesel production by green microalgae, Scenedesmus sp. Renewable Energy 135:617-625. https://doi. org/10.1016/j.renene.2018.12.056

Wang H, Xiong H, Hui Z, Zeng X (2012) Bioresource technology mixotrophic cultivation of Chlorella pyrenoidosa with diluted primary piggery wastewater to produce lipids. Bioresour Technol 104:215-220. https://doi. org/10.1016/j.biortech.2011.11.020

Wang L, Min M, Li Y, Chen P, Chen Y, Liu Y, Wang Y, Roger, \& Ruan. (2010) Cultivation of green algae Chlorella sp. in different wastewaters from municipal wastewater treatment plant. Appl Biochem Biotechnol 162:1174-1186. https://doi.org/10.1007/s12010-009-8866-7

Wang M, Yang H, Ergas SJ, Steen P (2015) A novel shortcut nitrogen removal process using an algal-bacterial consortium in a photo-sequencing batch reactor (PSBR). Water Res 87:38-48. https://doi.org/10.1016/j.watre s.2015.09.016

Whitton R, Mevel AL, Pidou M, Ometto F, Villa R, Jefferson B (2016) In fl uence of microalgal $\mathrm{N}$ and $\mathrm{P}$ composition on wastewater nutrient remediation. Water Res 91:371-378. https://doi.org/10.1016/j.watres.2015.12.054 
Xin L, Hong-ying H, Jia Y (2010) Lipid accumulation and nutrient removal properties of a newly isolated freshwater microalga, Scenedesmus sp. LX1, growing. New Biotechnology 27(1):59-63. https://doi.org/10.1016/j. nbt.2009.11.006

Yang I, Salama E, Kim J, Govindwar SP, Kurade MB, Lee M, Roh H, Jeon B (2016) Cultivation and harvesting of microalgae in photobioreactor for biodiesel production and simultaneous nutrient removal. Energy Conersion Manag 117:54-62. https://doi.org/10.1016/j.enconman.2016.03.017

Yu H, Kim J, Lee C (2019) Nutrient removal and microalgal biomass production from different anaerobic digestion effluents with Chlorella species. Sci Rep 9(6123):1-13. https://doi.org/10.1038/s41598-019-42521-2

Yuan X, Wang M, Park C, Sahu AK, Ergas SJ, Yuan X, Wang M, Park C, Sahu AK, Ergas SJ (2012) Microalgae growth using high-strength wastewater followed by anaerobic co-digestion. Water Environ Res 84(5):396-404. https://doi.org/10.2175/10614301

Zhu L, Wang Z, Shu Q, Takala J, Hiltunen E, Feng P, Yuan Z (2013) Nutrient removal and biodiesel production by integration of freshwater algae cultivation with piggery wastewater treatment. Water Res 47(13):4294-4302. https://doi.org/10.1016/j.watres.2013.05.004

\section{Publisher's Note}

Springer Nature remains neutral with regard to jurisdictional claims in published maps and institutional affiliations.

\section{Submit your manuscript to a SpringerOpen ${ }^{\circ}$ journal and benefit from:}

- Convenient online submission

- Rigorous peer review

- Open access: articles freely available online

- High visibility within the field

- Retaining the copyright to your article

Submit your next manuscript at $\boldsymbol{\nabla}$ springeropen.com 